\title{
Isolation and Identification of Microorganism, Producing Microbial Alkaline Proteinase Inhibitor (MAPI) ${ }^{\dagger}$
}

\author{
Sawao Murao and Takashi Watanabe \\ Laboratory of Applied Microbiology, Department of Agricultural Chemistry, \\ University of Osaka Prefecture, Sakai, Osaka 591, Japan
}

Received April 21, 1978

\begin{abstract}
In the screening of actinomycetes' culture filtrate for inhibitor of subtilisin and various microbial alkaline proteinases, a novel inhibitor was found in a cultured broth of strain WT-27. This inhibitor was named as MAPI, abbreviation of microbial alkaline proteinase inhibitor.

Judging from the morphological and physiological properties of the actinomycetes which produced MAPI, this strain was identified as Streptomyces nigrescens.

For the production of MAPI, this strain was aerobically cultured at $25 \sim 27^{\circ} \mathrm{C}$ in a jar fermentor which contained an optimum medium consisting of polypepton $3 \%$, meat extract $1 \%$, glucose $1 \%, \mathrm{NaCl} 0.1 \%, \mathrm{~K}_{2} \mathrm{HPO}_{4} 0.1 \%$ and $\mathrm{MnSO}_{4} \cdot n \mathrm{H}_{2} \mathrm{O} 0.0001 \%, \mathrm{pH} 7.0$. The production of MAPI reached its maximum after $21 \sim 24 \mathrm{hr}$ cultivation.

MAPI had an inhibitory activity against various microbial alkaline proteinases, $\alpha$-chymotrypsin and papain but not against trypsin, kallikrein, thermolysin, or pepsin.
\end{abstract}

As reported by Murao and Sato, ${ }^{1)}$ this laboratory investigated proteinaceous proteinase inhibitor, S-SI, which inhibited proteolytic activity of subtilisin $\mathrm{BPN}^{\prime}$ [EC 3.4.21.14] and various microbial alkaline serine proteinases. Proteinaceous proteinase inhibitors of microbial origin such as Plasminostreptin ${ }^{21}$ and AP-I, ${ }^{3}$ ' having an inhibitory action against subtilisin, were also reported. However, no subtilisin inhibitor of oligopeptide nature from micobial origin has been reported so far. Such a peptidic substrate-analogous subtilisin inhibitor may be a useful tool in the investigations of the substrate binding sites or the active sites of susceptible enzymes, as reported in the case of subtilisin BPN' $^{\prime}$ with various peptide chloromethyl ketone derivatives. ${ }^{4 \sim 7}$ ) In addition, such an inhibitor will serve as a specific probe for the investigation of the biological function of proteinases in microbes.

As reported in the previous paper, ${ }^{8}$ the authors screened culture filtrates of actinomycetes to obtain a peptidic subtilisin inhibitor and found a novel inhibitor (MAPI), having potent inhibitory actions against subtilisin

\footnotetext{
$t$ A part of this investigation was presented at the Annual Meeting of the Agricultural Chemical Society of Japan at Nagoya, April, 1978.
}

$\mathrm{BPN}^{\prime}$ and various microbial alkaline proteinases.

In this paper, the identification of the MAPIproducing actinomycetes and the production of MAPI are reported. Preliminary characterizations of MAPI are also reported. ${ }^{8}$

\section{MATERIALS AND METHODS}

Inhibitor-producing microorganism. Microorganism employed in this paper was a strain numbered WT -27 which was isolated from soil.

Enzymes and reagents. Crystalline subtilisin BPN' (Lot. 7749102, $100 \times 10^{4} \mathrm{PUN} / \mathrm{g}$ ) was obtained as lyophilized powder from Nagase Sangyo Co., Osaka. Subtilisin type Carlsberg (crystallized and lyophilized), $a$-chymotrypsin (bovine pancreatic, 3 times crystallized and lyophilized), papain ( 2 times crystallized and lyophilized) and pepsin ( 2 times crystallized and lyophilized) were purchased from Sigma Chemical Co. Kalli krein for medical use was a product of Bayer Co. Thermolysin ( 3 times crystallized and lyophilized) was purchased from Seikagaku Kogyo Co., Tokyo. Alkaline proteinase of Aspergillus melleus (crystallized and lyophilized) $\left.{ }^{9}\right)$ was kindly supplied from Amano Pharmaceutical Co., Nagoya. Crystallized alkalophilic proteinase of Streptomyces sp. was a kind gift of Dr. T. Yamamoto, Faculty of Science, Osaka City University, Osaka. ${ }^{10}$ Crystallized alkaline proteinase of Cephalasporium sp. was kindly supplied by Fujisawa Pharmaceutical Co., Osaka. ${ }^{11)}$ 
The substrates, $\mathrm{N}^{\alpha}$-benzoyl-L-arginine ethyl ester (Bz-Arg-OEt), $\mathrm{N}^{\alpha}$-benzoyl-L-arginine amide (Bz-Arg$\mathrm{NH}_{2}$ ) and $\mathrm{N}^{\alpha}$-benzoyl-L-arginine-4-nitroanilide $(\mathrm{Bz}-$ Arg-NPhNO ${ }_{2}$ ) were purchased from the Foundation for Promotion of Protein Research, Institute for Protein Research, Osaka. Casein according to Hammarstein was purchased from Wako Pure Chemical Co., Osaka.

\section{Assay system for inhibitory action of MAPI against various proteinases}

(1). Estimation of inhibitory activity of MAPI against subtilisin BPN'. A fourth $\mathrm{ml}$ of subtilisin BPN' solution $\left(100 \mu \mathrm{g} / \mathrm{ml}\right.$ in $0.05 \mathrm{M} \mathrm{Na}_{2} \mathrm{~B}_{4} \mathrm{O}_{7}-\mathrm{Na}_{2} \mathrm{CO}_{3}$ buffer pH 9.5) and $0.25 \mathrm{ml}$ of inhibitor solution (in the same buffer) were allowed to react for $10 \mathrm{~min}$ at $37^{\circ} \mathrm{C}$ before addition of $1.5 \mathrm{ml}$ of $1.33 \%$ casein (in the same buffer). After a further $10 \mathrm{~min}$ incubation, the reaction was terminated by addition of $2 \mathrm{ml}$ of $0.44 \mathrm{M}$ trichloroacetic acid. The precipitate formed was filtrated after standing for $20 \mathrm{~min}$ at $37^{\circ} \mathrm{C}$. To $0.5 \mathrm{ml}$ of the filtrate, $2.5 \mathrm{ml}$ of $0.44 \mathrm{M} \mathrm{Na}_{2} \mathrm{CO}_{3}$ and $0.5 \mathrm{ml}$ of Folin-Ciocalteu reagent (Wako Pure Chemical Co., diluted 2 times) were added. After standing for $20 \mathrm{~min}$ at $37^{\circ} \mathrm{C}$, the absorbance of the sample $(I)$ was read at $660 \mathrm{~nm}$. Values were also estimated for an enzyme control $(E)$ without inhibitor, a sample blank $(I b)$ and enzyme blank $(E b)$ using buffer instead of the enzyme solution. The inhibition rate of inhibitor was calculated as a percentage of the enzyme activity using the equation:

$$
\frac{(E-E b)-(I-I b)}{(E-E b)} \times 100
$$

One inhibitor unit is defined as the dose by which subtilisin BPN' is inhibited $50 \%$ of its caseinolytic activity. The correlation between the amount of MAPI and inhibition against subtilisin BPN' was not linear, as shown in Fig. 1. It is necessary to determine the inhibitory activity by the standard curve, and dilution of

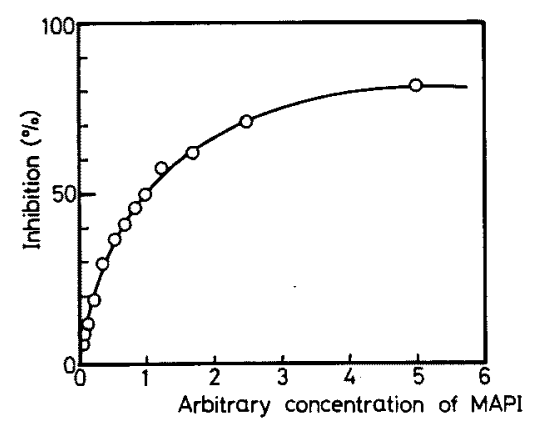

Fio. 1. Standard Curve for Assaying MAPI by the Casein-Folin Color Method.

A fourth $\mathrm{ml}$ of subtilisin BPN' solution was incubated with $0.25 \mathrm{ml}$ of MAPI solution for $10 \mathrm{~min}$ at $37^{\circ} \mathrm{C}$ and residual caseinolytic activity of subtilisin BPN' was assayed. inhibitor solution that gave about $50 \%$ inhibition had been used.

(2). Microbial alkaline proteinases, trypsin, achymotrypsin, thermolysin and pepsin (caseinolytic activity). Inhibitory actions of MAPI against these proteinases were estimated by the same procedure of subtilisin assay system described above, except buffer systems or enzyme concentrations. A fourth $\mathrm{ml}$ of subtilisin type Carlsberg $(100 \mu \mathrm{g} / \mathrm{ml}$ in $0.05 \mathrm{M}$ borate buffer $\mathrm{pH} 9.5$ ), Cephalosporium $\mathrm{sp}$. alkaline proteinase $(100 \mu \mathrm{g} / \mathrm{ml}$ in $0.05 \mathrm{M}$ borate buffer $\mathrm{pH} 9.5)$, Streptomyces sp. alkalophilic proteinase $(76 \mu \mathrm{g} / \mathrm{ml}$ in $0.05 \mathrm{M}$ borate buffer $\mathrm{pH} 11.5$ ), Aspergillus melleus semialkaline proteinase $(100 \mu \mathrm{g} / \mathrm{ml}$ in $0.05 \mathrm{M}$ phosphate buffer pH 8.0), trypsin $(100 \mu \mathrm{g} / \mathrm{ml}$ in $0.05 \mathrm{M}$ phosphate buffer pH 7.4), $\alpha$-chymotrypsin $(100 \mu \mathrm{g} / \mathrm{ml}$ in $0.05 \mathrm{M}$ phosphate buffer $\mathrm{pH} 7.4)$, thermolysin $(32 \mu \mathrm{g} / \mathrm{ml}$ in 0.05 phosphate buffer pH 7.4) and pepsin $(400 \mu \mathrm{g} / \mathrm{ml}$ in $0.1 \mathrm{M}$ citrate buffer $\mathrm{pH} 1.6$ ) and $0.25 \mathrm{ml}$ of the buffer with or without inhibitor were preincubated for $10 \mathrm{~min}$ at $37^{\circ} \mathrm{C}$, and the remaining enzyme activities were estimated.

(3). Papain (caseinolytic activity). Two tenth $\mathrm{ml}$ of papain solution $(125 \mu \mathrm{g} / \mathrm{ml}$ in $0.05 \mathrm{M}$ phosphate buffer $\mathrm{pH} 7.4), 0.1 \mathrm{ml}$ of activator solution $(0.05 \mathrm{M}$ cysteine and $0.02 \mathrm{M}$ ethylenediamine tetraacetic acid solution, $\mathrm{pH} \mathrm{7.4)}$ and $0.2 \mathrm{ml}$ of the buffer with or without inhibitor were preincubated for $5 \mathrm{~min}$ at $37^{\circ} \mathrm{C}$ before addition of $1.5 \mathrm{ml}$ of $1.33 \%$ casein (in the same buffer). After a further $10 \mathrm{~min}$ incubation, the reaction was terminated by addition of $2 \mathrm{ml}$ of $0.44 \mathrm{M}$ trichloroacetic acid. The precipitate formed was filtrated after standing for $20 \mathrm{~min}$ at $37^{\circ} \mathrm{C}$. The absorbance of the filtrate was read at $280 \mathrm{~nm}$.

\section{(4). Papain (amidase activity)}

a). Against $\mathrm{Bz}-\mathrm{Arg}-\mathrm{NPhNO}$. A fourth $\mathrm{ml}$ of the enzyme solution $(400 \mu \mathrm{g} / \mathrm{ml}$ in $0.05 \mathrm{M}$ Tris- $\mathrm{HCl}$ buffer $\mathrm{pH} 7.5$ ) and $0.25 \mathrm{ml}$ of the same buffer with or without inhibitor were preincubated for $5 \mathrm{~min}$ at $37^{\circ} \mathrm{C}$ before addition of $2.5 \mathrm{ml}$ of $0.001 \mathrm{M} \mathrm{Bz}-\mathrm{Arg}-\mathrm{NPhNO}_{2}$ (in the same buffer containing $0.005 \mathrm{M}$ cysteine, $0.002 \mathrm{M}$ ethylenediamine tetraacetic acid and $1 \%(\mathrm{v} / \mathrm{v})$ dimethyl sulfoxide). After a further $25 \mathrm{~min}$ incubation, the reaction was terminated by addition of $0.5 \mathrm{ml}$ of $30 \%$ acetic acid and read the absorbance at $410 \mathrm{~nm}$.

b). Against $B z-A r g-N_{2}$. A fourth $\mathrm{ml}$ of the enzyme solution $(400 \mu \mathrm{g} / \mathrm{ml}$ in $0.05 \mathrm{M}$ phosphate buffer $\mathrm{pH} 6.0$ ), $0.5 \mathrm{ml}$ of $0.02 \mathrm{M} \mathrm{2-mercaptoethanol} \mathrm{(in} \mathrm{the}$ same buffer) and $0.25 \mathrm{ml}$ of the buffer with or without inhibitor were preincubated for $5 \mathrm{~min}$ at $37^{\circ} \mathrm{C}$ before addition of $1.0 \mathrm{ml}$ of $0.01 \mathrm{M} \mathrm{Bz}-\mathrm{Arg}-\mathrm{NH}_{2}$ (in the same buffer). After a further $20 \mathrm{~min}$ incubation, an aliquot of $0.2 \mathrm{ml}$ was used for analysis by the ninhydrin method. ${ }^{12)}$

(5). Kallikrein. A tenth $\mathrm{ml}$ of kallikrein solution $(500 \mu \mathrm{g} / \mathrm{ml}$ in $0.05 \mathrm{M}$ Tris-HCl buffer $\mathrm{pH} 8.2)$ and $0.7 \mathrm{ml}$ 
of the buffer with or without inhibitor were preincubated for $10 \mathrm{~min}$ at $37^{\circ} \mathrm{C}$ before addition of $2.0 \mathrm{ml}$ of $0.1 \mathrm{M} \mathrm{Bz-Arg-OEt}$ (in the same buffer). After a further $80 \mathrm{~min}$ incubation, the residual substrate was estimated by means of the alkaline hydroxylamine procedure described by Roberts. ${ }^{13)}$

Identification of strain $W T-27$. The taxonomic criteria and methods, according to the reports of the Infernational Streptomyces Project (ISP), ${ }^{14)}$ were employed in the present study, and the identification was made by the description of Bergey's Manual of Determinative Bacteriology 8 th ed., ${ }^{15)}$ and ISP reports. ${ }^{16)}$ The cell wall constituents of the strain was determined by the methods described by Becker et $a l^{17}{ }^{17}$

\section{RESULTS AND DISCUSSION}

\section{Identification of strain $W T-27$}

\section{Table I. Morphological Characteristics and Cell Wall Composition of Strain WT-27}

\begin{tabular}{|c|c|}
\hline Spore chain morphology & $\begin{array}{l}\text { Section Spirales, simple } \\
\text { branching }\end{array}$ \\
\hline Spore ornamentation & Smooth \\
\hline Spore size & $\begin{array}{l}\text { Spherical, } 0.5 \sim 0.8 \\
\quad \times 0.8 \sim 1.0 \mu\end{array}$ \\
\hline $\begin{array}{l}\text { Special morphological } \\
\text { characteristics }\end{array}$ & $\begin{array}{l}\text { Coalesced masses of spores } \\
\text { (hygroscopic type) }\end{array}$ \\
\hline Spore color en masse & Gray color series \\
\hline $\begin{array}{l}\text { Cell wall constituents } \\
\text { Amino acids }\end{array}$ & $\begin{array}{l}\text { LL-2,6-Diaminopimelic } \\
\text { acid, glycine, glutamic } \\
\text { acid and alanine }\end{array}$ \\
\hline $\begin{array}{l}\text { Amino sugars and } \\
\text { sugars }\end{array}$ & $\begin{array}{l}\text { Glucosamine, muramic } \\
\text { acid and glucose }\end{array}$ \\
\hline
\end{tabular}

Table II. Physiological. Characteristics of Strain WT-27

Liquefaction of gelatin (glucose-peptone-gelatin medium), incubated at $27 \sim 30^{\circ} \mathrm{C}$ for 3 weeks: negative

Hydrolysis of starch (inorganic salts-starch agar): positive

Milk: peptonization and non-coagulation

Production of melanoid pigments (tyrosine agar, peptone-yeast-iron agar and tryptone-yeast broth): negative

Presence of tyrosinase enzyme (synthetic tyrosine agar): negative

Carbon utilization (Pridham-Gottlieb basal agar) ${ }^{a}$ : D-glucose $(++)$, D-xylose $(+)$, L-arabinose $(-)$, L-rhamnose $(-)$, D-fructose $(+)$, D-galactose $(++)$, raffinose $(++)$, D-mannitol $(++)$, $i$-inositol $(++)$, salicin (not determined), sucrose $(++)$.

$a++$, fair; + , moderate; - , poor or no utilization.
Strain WT-27 was freshly isolated from soil samples collected in Osaka Prefecture, in the course of our screenings of enzyme inhibitorproducing microorganisms.

The morphological and physiological properties, shown in Tables I and II, suggest

Table III. Cultural Characteristics of Strain WT-27 ON ISP Media after INCUBATION FOR 3 WEEKS AT $27 \sim 30^{\circ} \mathrm{C}$

On sucrose-nitrate agar

G: poor, light gray.

AM: very sparse, colored white, if any.

DP: none.

On glucose-asparagine agar

$\mathrm{G}$ : moderate, yellowish white to light brownish gray.

AM: sparse, colored white to light brownish gray, if any.

DP: pale yellow.

On glycerol-asparagine agar (ISP Med. No. 5)

$\mathrm{G}$ : abundant, grayish yellow brown.

AM: light brownish gray to dark gray.

DP: pale yellow.

On salts-starch agar (ISP Med. No. 4)

$\mathrm{G}$ : abundant, light olive gray to light brownish gray.

AM : light gray to light brownish gray with dark gray patches.

DP: pale yellow.

On tyrosine agar (ISP Med. No. 7)

$G$ : abundant, pale yellowish brown to light brownish gray.

AM: white to light gray.

DP: pale yellow.

On nutrient agar

$G$ : abundant, pale yellowish brown.

AM: sparse, colored white, if any.

DP: pale yellowish brown.

On yeast-malt agar (ISP Med. No. 2)

$G$ : abundant, grayish yellow brown.

AM: light gray to light brownish gray with dark gray patches.

DP: pale greenish yellow.

On oatmeal agar (ISP Med. No. 3)

$\mathrm{G}$ : abundant, pale yellowish brown to light olive gray.

AM : light gray to light brownish gray with dark gray patches.

DP: pale yellow.

G: growth of colony and color of substrate mycelium.

AM : growth and mass color of mature sporulating aerial mycelium.

DP: diffusible color. 
TABle IV. Comparison of Strain WT-27, S. hygroscopicus subse. globosus and $S$. nigrescens

\begin{tabular}{|c|c|c|c|}
\hline Characteristics Strain & $\mathrm{WT}-27$ & $\begin{array}{l}\text { S. hygroscopicus } \\
\text { subsp. globosus }\end{array}$ & S. nigrescens \\
\hline Spore chain morphology & Closed spiral, long & $\begin{array}{l}\text { Closed spiral, fri- } \\
\text { zzled and lumpy }\end{array}$ & Closed spiral, long \\
\hline \multicolumn{4}{|l|}{ Cultural characteristics ${ }^{a}$} \\
\hline $\mathrm{G}$ on tyrosine agar & $\begin{array}{l}\text { Abundant, light } \\
\text { brownish gray }\end{array}$ & Poor, colorless & Moderate, light gray \\
\hline AM on tyrosine agar & Light gray & None & Light gray \\
\hline $\begin{array}{l}\text { DP on starch agar, glucose- } \\
\text { asparagine agar and } \\
\text { tyrosine agar }\end{array}$ & Pale yellow & None & Pale yellow \\
\hline $\begin{array}{l}\text { AM on nutrient agar } \\
\text { Carbon utilization }\end{array}$ & Poor, white & None & Poor, white \\
\hline L-Arabinose & - & \pm & - \\
\hline D-Xylose & + & \pm & + \\
\hline D-Fructose & + & ++ & + \\
\hline L-Rhamnose & - & - & - \\
\hline $\begin{aligned} \mathrm{G}: & \text { growth of colony and cc } \\
\text { AM : } & \text { growth and mass color } \\
\text { DP : } & \text { diffusible color. }\end{aligned}$ & $\begin{array}{l}\text { substrate mycelium. } \\
\text { Ire sporulating aerial }\end{array}$ & Iycelium. & \\
\hline
\end{tabular}

that strain WT-27 should be allocated to genus Streptomyces. Furthermore, the cell wall of strain WT-27 contained LL-isomer of 2,6diaminopimelic acid and glycine as the major constituents, i.e., cell wall type I according to Lechevalier and Lechevalier. ${ }^{18}$ ) The cultural characteristics on various media are shown in Table III. According to the primary keys noted in Bergey's Manual, ${ }^{15}$ s strain WT-27 belonged to (GY.S.C-.SM) series of streptomyces. Among the reported 16 species of "hygroscopic" (GY.S.C-.SM) streptomyces, Streptomyces hygroscopicus subsp. globosus and Streptomyces nigrescens were most similar to strain WT-27 in the carbon utilization pattern. Therefore, Streptomyces $h y$ groscopicus subsp. globosus ATCC 14607, Streptomyces nigrescens ATCC 23941 and strain WT-27 were comparatively studied. The results are summarized in Table IV, Streptomyces hygroscopicus subsp. globosus did not produce diffusible pigment but strain WT-27 and Streptomyces nigrescens produced pale yellow pigment on various media. Judging from the additional differences in the spore chain morphology, growth on tyrosine agar and utilization of $\mathrm{D}$-fructose, it may be reasonable to identify strain WT-27 as Strepto- myces nigrescens. Accordingly, the author named strain WT-27 as Streptomyces nigrescens WT-27.

\section{Cultural conditions for the production of $M A P I$}

Cultural conditions such as composition of medium, metal ions, $\mathrm{pH}$ and temperature have been known to be important in the production of secondary metabolites. The production of MAPI by Streptomyces nigrescens WT-27 under various conditions was investigated.

Effect of carbon source. The effects of glucose and soluble starch concentration on the production of MAPI were studied. The results are shown in Table $\mathrm{V}$, addition of glucose or soluble starch to the basal broth was effective for the production of MAPI. The increase in starch concentration had an inhibitory effect for the production of MAPI. Thus, the optimum concentration of glucose was about $1 \%(w / v)$.

Effect of nitrogen source. The results of addition of various nitrogen sources to the basal medium ( $1 \%$ glucose and salts mixture) are shown in Table VI. Polypepton was effective nitrogen source for the production of 
Table V. EFfect of Concentration of Carbon Source on Production of MAPI

One ml of seed culture (medium; basal medium plus $1 \%$ glucose, incubated for $48 \mathrm{hr}$ at $30^{\circ} \mathrm{C}$ on a reciprocal shaker) was inoculated into $100 \mathrm{ml}$ medium in $500 \mathrm{ml}$ flask and cultured at $30^{\circ} \mathrm{C}$ for $48 \mathrm{hr}$ on a reciprocal shaker. Basal medium: polypepton $1 \%$, meat extract $1 \%, \mathrm{NaCl} 0.3 \%, \mathrm{pH} 7.0$.

\begin{tabular}{|c|c|c|c|}
\hline $\begin{array}{l}\text { Carbon } \\
\text { source } \\
(\%)\end{array}$ & $\begin{array}{c}\text { Final } \\
\text { pH }\end{array}$ & Growth & $\begin{array}{c}\text { Inhibitor } \\
\text { activity } \\
\text { (unit } / \mathrm{ml} \text { broth) }^{a}\end{array}$ \\
\hline \multicolumn{4}{|l|}{ Glucose } \\
\hline 0.5 & 8.3 & + & 1.0 \\
\hline 1.0 & 7.6 & + & 2.4 \\
\hline 2.0 & 6.1 & + & 2.4 \\
\hline 3.0 & 5.2 & + & 2.4 \\
\hline 4.0 & 5.2 & + & 2.3 \\
\hline \multicolumn{4}{|c|}{ Soluble starch } \\
\hline 0.5 & 8.3 & ++ & 1.9 \\
\hline 1.0 & 8.3 & ++ & 2.1 \\
\hline 2.0 & 8.3 & $+t$ & 1.4 \\
\hline 3.0 & 8.3 & $+t$ & 1.3 \\
\hline 4.0 & 8.2 & ++ & 1.1 \\
\hline None & 8.5 & + & 0.8 \\
\hline
\end{tabular}

a Inhibitor activity was calculated from the per cent inhibition of caseinolytic activity of subtilisin BPN' $^{\prime}$ as detailed in MATERIALS AND METHODS.

Table VI. Effect of Nitrogen Source oN Production of MAPI

Each nitrogen source was added to the basal medium to give desired concentration. Composition of the basal medium was as follows; glucose $1 \%, \mathrm{~K}_{2} \mathrm{HPO}_{4}$ $0.1 \%, \mathrm{NaCl} 0.1 \%, \mathrm{MgSO}_{4} \cdot 7 \mathrm{H}_{2} \mathrm{O} 0.0001 \%, \mathrm{MnSO}_{4}$. $n \mathrm{H}_{2} \mathrm{O} 0.0001 \%, \mathrm{pH} 7.0$. See the legend for Table V for the cultivation conditions.

\begin{tabular}{|c|c|c|c|c|}
\hline \multicolumn{2}{|l|}{$\begin{array}{c}\text { Nitrogen } \\
\text { source } \\
(\%)\end{array}$} & \multirow{2}{*}{$\begin{array}{c}\begin{array}{c}\text { Final } \\
\text { pH }\end{array} \\
5.0\end{array}$} & \multicolumn{2}{|c|}{$\begin{array}{l}\text { Inhibitor } \\
\text { growth activity } \\
\text { (unit/ml broth) }\end{array}$} \\
\hline & 1 & & + & 2.4 \\
\hline & 2 & 8.0 & + & 3.5 \\
\hline Polypepton & 3 & 8.0 & + & 4.0 \\
\hline & 4 & 8.3 & ++ & 4.4 \\
\hline & 5 & 8.2 & ++ & 4.2 \\
\hline & 1 & 7.1 & + & 1.7 \\
\hline Meat extract & 2 & 8.1 & + & 1.7 \\
\hline & 3 & 7.9 & + & 1.9 \\
\hline $\begin{array}{l}\text { Amino acids } \\
\text { mixture }\end{array}$ & 2 & 8.2 & +++ & 3.4 \\
\hline Soy bean flake & & & & \\
\hline extract & 2 & 5.6 & + & 0.3 \\
\hline Polypepton plus & 3 & 8.0 & +++ & 5.3 \\
\hline Meat extract & 1 & & & \\
\hline
\end{tabular}

MAPI. Thus, the optimum composition and concentration of nitrogen source was determined as $3 \%$ polypepton plus $1 \%$ meat extract $(w / v)$.

Optimum conditions. Other cultural conditions such as inorganic salts, initial $\mathrm{pH}$ of the medium and cultivation temperature were also investigated for the maximum production of MAPI. As shown in Table VII, the optimum conditions for the production of MAPI were obtained.

Table VII. Optimum CONDITIONS for Production of MAPI

\begin{tabular}{ll}
\hline Polypepton & $3 \%$ \\
Glucose & $1 \%$ \\
Meat extract & $1 \%$ \\
$\mathrm{NaCl}$ & $0.1 \%$ \\
$\mathrm{~K}_{2} \mathrm{HPO}_{4}$ & $0.1 \%$ \\
$\mathrm{MnSO}_{4} \cdot n \mathrm{H}_{2} \mathrm{O}$ & $0.0001 \%$ \\
Initial pH & 7.0 \\
Temperature & $25 \sim 27^{\circ} \mathrm{C}$ \\
\hline
\end{tabular}

Production of MAPI with jar fermentor. Streptomyces nigrescens WT-27 was grown in 10 liter batches in 20 liter jar fermentor at $25 \sim 27^{\circ} \mathrm{C}$. The typical time course of cultivation is shown in Fig. 2. The production of MAPI showed its maximum after $21 \sim 24 \mathrm{hr}$ cultivation time when glucose was almost consumed and $\mathrm{pH}$ of the broth was tending upward. The amount of MAPI produced was about $100 \mathrm{mg}$ per liter of cultured broth.

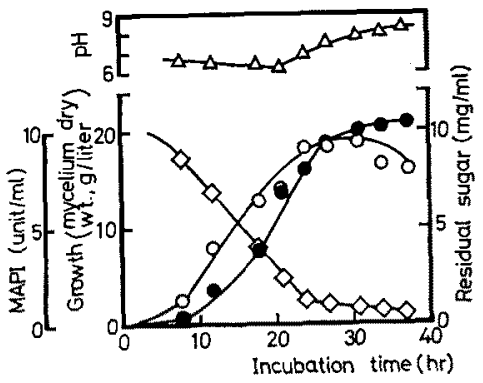

Fig. 2. Time Course of MAPI Production.

Cultural conditions are shown in Table VII. Streptomyces nigrescens WT-27 was grown in 10 liter of the optimum medium in a jar fermentor of 20 liter volume. Air flow, $10 \mathrm{liter} / \mathrm{min}$; agitation, $200 \mathrm{rpm} . \Delta-\Delta$, pH; ○-O, MAPI; -๑, growth; $\diamond-$, residual sugar. 


\section{Preliminary characterization of $M A P I$}

The isolation procedure of MAPI from cultured broth of Streptomyces nigrescens WT-27 consisted of a fractionation with ammonium sulfate, active carbon adsorption, Amberlite IRC-50, silica gel column chromatography and gel filtration on Sephadex LH-20, as described previously. ${ }^{8}$ ) The yield of purified MAPI was $50 \sim 30 \mathrm{mg}$ per liter of cultured broth.

MAPI was a dialyzable and heat stable material, and gave a positive Rydon-Smith reaction, negative ninhydrin and anthrone reactions. Therefore, MAPI was likely to be a type of peptide inhibitor.

The inhibitory actions on various proteinases are summarized in Table VIII, indicating that MAPI had inhibitory activities against various microbial alkaline proteinases, $\alpha$-chymotrypsin and papain, but not against trypsin, kallikrein, thermolysin, and pepsin.

\section{TABLE VIII. InhIBITORY SPECTRUM OF MAPI on Various Proteinases}

Inhibitory action of MAPI was estimated by measuring residual enzyme activity after incubation of each enzyme with MAPI $(50 \mu \mathrm{g})$. See Materials AND METHODS for detailed assay systems.

Inhibitory ratings used are as follows: + , more than $80 \%$ inhibition; - , less than $10 \%$ inhibition of enzyme activity.

\begin{tabular}{|c|c|c|}
\hline Proteinase & Substrate & Inhibition \\
\hline Subtilisin BPN' & Casein & + \\
\hline Subtilisin Carlsberg & Casein & + \\
\hline \multicolumn{3}{|l|}{ Streptomyces sp. } \\
\hline alkalophilic proteinase & Casein & + \\
\hline \multicolumn{3}{|l|}{ Aspergillus melleus } \\
\hline semialkaline proteinase & Casein & + \\
\hline \multicolumn{3}{|l|}{ Cephalosporium sp. } \\
\hline Trypsin & Casein & - \\
\hline$\alpha$-Chymotrypsin & Casein & + \\
\hline Kallikrein & $\mathrm{Bz}-\mathrm{Arg}-\mathrm{OEt}$ & - \\
\hline \multirow[t]{3}{*}{ Papain } & Casein & + \\
\hline & $\mathrm{Bz}-\mathrm{Arg}-\mathrm{NPhNO} \mathrm{N}_{2}$ & + \\
\hline & $\mathrm{Bz}-\mathrm{Arg}-\mathrm{NH}_{2}$ & + \\
\hline Thermolysin & Casein & - \\
\hline Pepsin & Casein & - \\
\hline
\end{tabular}

Among the peptide inhibitors of microbial origin known at present, MAPI had similar inhibitory specificities to chymotrypsin inhi- bitor "chymostatin" isolated from culture filtrates of various species of Streptomyces by Umezawa et al. ${ }^{19}$ / except for the inhibitory actions against micobial alkaline proteinases. MAPI, however, differed from "chymostatin" in the extent of inhibition against papain. In addition, "chymostatin" did not inhibit papainhydrolysis of $\mathrm{Bz}-\mathrm{Arg}-\mathrm{NH}_{2},{ }^{20)}$ whereas MAPI had a potent inhibitory action on papainhydrolysis of $\mathrm{Bz}-\mathrm{Arg}-\mathrm{NH}_{2}$ or $\mathrm{Bz}-\mathrm{Arg}-\mathrm{NPhNO}_{2}$.

The detailed description of the purification and characterization of MAPI will be presented later.

\section{REFERENCES}

1) S. Murao and S. Sato, Agric. Biol. Chem, 36, 160 (1972).

2) J. Kakinuma, H. Sugino, N. Moriya and M. Isono, Abstracts of Papers, Annual Meeting of Agricultural Chemical Society of Japan, Sendai, April, 1972, p. 261.

3) M. Uyeda, S. Yoshida, K. Suzuki and M. Shibata, Agric. Biol. Chem., 40, 1237 (1976).

4) E. Shaw and J. Ruscica, J. Biol. Chem., 243, 6312 (1968).

5) K. Morihara and T. Oka, Arch. Biochem. Biophys., 138, 526 (1970).

6) J. D. Robertus, R. A. Alden, J. J. Birktoft, J. Kraut, J. C. Powers and P. E. Wilcox, Biochemistry, 11, 2439 (1972).

7) J. C. Powers, M. O. Lively III and J. T. Tippett, Biochim. Biophys. Acta, 480, 246 (1977).

8) S. Murao and T. Watanabe, Agric. Biol. Chem., 41, 1313 (1977).

9) M. Ito and M. Sugiura, Yakugaku Zasshi, 12, 1583 (1968).

10) T. Nakanishi, Y. Matsumura, N. Minamiura and T. Yamamoto, Agric. Biol. Chem, 38, 37 (1974).

11) J. Yagi, T. Yano, K. Kubochi, S. Hattori, M. Ohashi, S. Sakai, K. Jomon and M. Ajisaka, $J$. Ferment. Technol., 50, 592 (1972).

12) S. Moore and W. H. Stein, J. Biol. Chem., 211, 907 (1954).

13) P. S. Roberts, ibid., 232, 285 (1958).

14) E. B. Shirling and D. Gottlieb, Int. J. Syst. Bacteriol., 16, 313 (1966).

15) "Bergey's Manual of Determinative Bacteriology," ed. by R. E. Buchanan and N. E. Gibbons, The Williams \& Wilkins Co., Baltimore, 1974.

16) E. B. Shirling and D. Gottlieb, Int. J. Syst. Bacteriol., 18, 69 (1968), 18, 279 (1968), 19, 391 (1969), 22, 265 (1972).

17) B. Becker, M. P. Lechevalier and H. A. Leche- 
valier, Appl. Microbiol., 13, 236 (1965).

18) M.P. Lechevalier and H. A. Lechevalier, Int. $J$. Syst. Bacteriol., 20, 435 (1970).

19) H. Umezawa, T. Aoyagi, H. Morishima, S. Kunimoto, M. Matsuzaki, M. Hamada and T. Take- uchi, J. Antibiot., 23, 425 (1970).

20) H. Umezawa and T. Aoyagi, "Proteinases in mammalian cells and tissues," ed. by A. J. Barrett, North-Holland Publishing Co., Amsterdam, 1977, p. 637. 